\section{Horticultural and Potential Breeding Value of Sugar Pea Landraces from Northwestern Spain}

\author{
J.M. Amurrio, A.M. de Ron, and M. Santalla \\ Misión Biológica de Galicia, CSIC, P.O. Box 28, 36080 Pontevedra, Spain
}

Additional index words. Pisum sativum, pod quality traits, snow pea, Chinese pea

\begin{abstract}
Twenty sugar pea (Pisum sativum L.) landraces common to northwestern Spain (Pontevedra), and potentially of interest as parental material, were evaluated at two locations and for $\mathbf{2}$ years to study the diversity among them for plant and pod physical quality traits. The main objective was to identify landraces that could be included in breeding programs. Highly significant differences among landraces were found for most of the pod traits, such as length, width, length/width index, fresh weight, and flowering date. Genotype-environment interactions were demonstrated for only three traits of the 10 investigated. High values for correlation coefficients were mostly found for pod traits, but highly significant ones (i.e., $P \leq \mathbf{0 . 0 1}$ ) were found for traits other than for pods. Most of the landraces were variable for qualitative and quantitative traits. PSM-0070, PSM0113, and PSM-0116 were superior for earliness and pod physical quality, but were heterogenous. PSM-0064, PSM-0066, PSM-0117, and PSM-0118 lacked pod parchment.
\end{abstract}

Sugar peas are grown for their tender green pods that lack the parchment layer on the inside of the pod (Sneddon, 1970). Horticulturally, the latter also is called snow pea, Chinese pea, and in Spain, "tirabeque" or "bisalto." Since sugar peas are consumed for their unripe pods, the horticultural cultivars used for this purpose must fulfill various pod quality requirements, such as for length, width, fresh weight, moisture content, shape, and absence of the parchment layer (Mateo Box, 1961).

In Spain, sugar peas are neither widely grown nor consumed and 'Capuchino' is the only improved cultivar currently grown for commercial purposes. Nevertheless, in the northwestern Iberian Peninsula (mainly a part of Spain named Galicia and northwestern Portugal), sugar pea is a popular fresh vegetable. Most of the varieties grown in these regions are mixtures of pure lines and can be considered unimproved landraces. Farmers save some seeds of the harvest in each growing generation for planting the next year. These landraces are an important genetic resource for plan breeders because of their considerable genotypic variation; their adaptation to subsistence agriculture; and their tolerance of low soil fertility, diseases, insects, and environmental fluctuation. However, their productiveness and quality as edible pods are not the best. Sugar pea landraces show differences in plant height, time to maturity, pod size and type, and seed characteristics. One of the primary objectives of sugar pea breeding programs is to eliminate the strings from the pods. Further aims are a

Received for publication 12 Oct. 1995. Accepted for publication 8 Apr. 1996. The cost of publishing this paper was defrayed in part by the payment of page charges. Under postal regulations, this paper therefore must be hereby marked advertisement solely to indicate this fact. in Pontevedra (northwestern Spain) has a program of germplasm collection and maintenance involving landraces of several cultivated species, including shelling peas, sugar peas, and field peas (Ron et al., 1991). Currently, there are 204 pea landraces maintained at the MBG germplasm collection. Twenty sugar pea landraces, mostly from the northwestern Iberian Peninsula, were identified in this collection.

The experiments reported herein were designed to measure the variability in this set of sugar pea landraces, with one commercial cultivar ('Capuchino') as control, and to identify landraces that are good material for inclusion in a breeding program. Emphasis has

${ }^{26}$ Capuchino' was the elite variety used as control. been placed on characters involved in earliness, pod physical quality, and presence or absence of the parchment layer in the pod.

\section{Materials and Methods}

Twenty sugar pea landraces plus the control (Table 1) were sown in a randomized complete-block design with two replications in each of 2 years (Winter 1991 and 1992) at two locations: Pontevedra (lat. $42^{\circ} 38^{\prime} \mathrm{N}$, long. $8^{\circ} 08^{\prime} \mathrm{W}, 20 \mathrm{~m}$ altitude, $14^{\circ} \mathrm{C}$ mean temperature, $1608 \mathrm{~mm}$ average rainfall) and Lalín (lat. $42^{\circ} 27^{\prime} \mathrm{N}$, long. $8^{\circ} 40^{\prime} \mathrm{W}, 490 \mathrm{~m}$ altitude, $11^{\circ} \mathrm{C}$ mean temperature, $1099 \mathrm{~mm}$ average rainfall). Each experimental plot consisted of a single $3.5-\mathrm{m}$ row, with row spacing of $80 \mathrm{~cm}$ and plant spacing of $25 \mathrm{~cm}$. Seed was hand-sown but overplanted by $100 \%$ and thinned to the desired population after emergence. Each plot was comprised of 15 plants. Plant traits evaluated were node of first flower and flowering date (number of days from sowing until 50\% of plants per experimental unit had at least one flower). The number of leaflets and tendrils was counted on five normal leaves from the middle part of five randomly selected plants per plot. Pod traits evaluated were fresh weight, moisture content (dried at $105^{\circ} \mathrm{C}$ for $72 \mathrm{~h}$ ), size (length, width), shape (length/width index), and number of ovules per pod, expressed as the mean of a sample of five pods.

Analysis of variance (ANOVA) was run for all traits over the 20 landraces plus the control. Year, location, and population were considered random variables. A partial correlation coefficient between all pairs of characters was calculated, according to Steel and Torrie (1981), using plot means.

\section{Results and Discussion}

Table 1. Geographical origin of 20 pea landraces from the northwestern Iberian Peninsula. ${ }^{2}$

\begin{tabular}{|c|c|c|c|c|}
\hline \multirow{2}{*}{$\begin{array}{l}\text { Geographical origin } \\
\text { Spain }\end{array}$} & \multicolumn{4}{|c|}{ Accession no. } \\
\hline & & & & \\
\hline Lugo (lat. $43^{\circ} 01^{\prime} \mathrm{N}$, long. $7^{\circ} 33^{\top} \mathrm{W}$ ) & PSM-0022 & PSM-0040 & PSM-0102 & \\
\hline Orense (lat. $42^{\circ} 21^{\prime} \mathrm{N}$, long. $7^{\circ} 51^{\prime} \mathrm{W}$ ) & PSM-0070 & & & \\
\hline Asturias (lat. $43^{\circ} 03^{\prime} \mathrm{N}$, long. $5^{\circ} 48^{\prime} \mathrm{W}$ ) & PSM-0191 & & & \\
\hline \multicolumn{5}{|l|}{ Portugal } \\
\hline \multirow[t]{2}{*}{ Bragança (lat. $41^{\circ} 48^{\prime} \mathrm{N}$, long. $6^{\circ} 46^{\prime} \mathrm{W}$ ) } & PSM-0110 & PSM-0111 & PSM-0112 & PSM-0113 \\
\hline & PSM-0114 & PSM-0115 & PSM-0116 & PSM-0117 \\
\hline \multirow[t]{2}{*}{ Vila Real (lat. $41^{\circ} 16^{\prime} \mathrm{N}$, long. $7^{\circ} 50^{\prime} \mathrm{W}$ ) } & PSM-0064 & PSM-0066 & PSM-0118 & PSM-0122 \\
\hline & PSM-0123 & PSM-0124 & PSM-0125 & \\
\hline
\end{tabular}

Significant differences among populations were found for flowering date, length, width, length/width index, and fresh weight of pod (Table 2), indicating that these pod physical versity among the populations. These results agree with those presented by Amurrio et al. (1993) for flowering date and pod length and width. Variation within landraces also existed, but mainly in qualitative traits. We do not consider the degree of variation in quantitative traits within accessions big enough to be of importance. Therefore, each accession, rather than the individual plant, was the experimental unit. quality traits appropriately evaluated the di- 
Breeding, Cultivars, Rootstocks, \& Germplasm Resources

Table 2. Mean squares from the analyses of variance of plant and pod traits in sugar pea populations from the northwestern Iberian Peninsula.

\begin{tabular}{|c|c|c|c|c|c|c|c|c|c|}
\hline \multirow[b]{3}{*}{ Trait } & \multicolumn{9}{|c|}{ Mean square } \\
\hline & \multicolumn{9}{|c|}{ Sources of variation $^{2}$} \\
\hline & $\mathrm{Y}$ & $\mathrm{L}$ & $\mathrm{Y} \times \mathrm{L}$ & $\mathrm{R}(\mathrm{Y} \times \mathrm{L})$ & $\mathrm{P}$ & $\mathrm{Y} \times \mathrm{P}$ & $\mathrm{L} \times \mathrm{P}$ & $\mathrm{Y} \times \mathrm{L} \times \mathrm{P}$ & E \\
\hline \multicolumn{10}{|l|}{ Plant } \\
\hline Node of first flower & 2.80 & $158.22^{* *}$ & 0.21 & 1.95 & 9.38 & 1.76 & $8.56^{* *}$ & 0.89 & 1.59 \\
\hline Flowering date (days) & 87.1 & $29887.5^{*}$ & 160.4 & 65.0 & $748.6^{* *}$ & $95.9^{*}$ & 44.8 & 40.1 & 51.7 \\
\hline Number of leaflets & 4.83 & 30.44 & 6.55 & 2.29 & 0.76 & $0.44^{* *}$ & 0.51 & 0.30 & 0.31 \\
\hline Number of tendrils & 53.00 & 3.12 & 7.42 & $0.92^{* *}$ & 0.83 & 1.14 & 0.51 & 0.25 & 0.57 \\
\hline \multicolumn{10}{|l|}{ Pod } \\
\hline Length (mm) & 3193.5 & 1020.8 & 421.8 & 29.8 & $913.6^{* *}$ & 109.3 & 155.8 & 126.4 & 93.3 \\
\hline Width (mm) & 49.52 & 19.13 & 6.16 & 1.73 & $42.89^{* *}$ & 3.66 & 6.09 & 5.21 & 3.78 \\
\hline Length/width index & 1.72 & 0.32 & 0.23 & $0.26^{*}$ & $0.69^{* *}$ & 0.17 & 0.12 & 0.12 & 0.10 \\
\hline Number of ovules & 4.33 & 0.24 & 0.83 & 0.05 & 0.92 & 0.18 & 0.20 & 0.23 & 0.18 \\
\hline Fresh weight (g) & 10.17 & 8.40 & 0.46 & 0.48 & $7.93^{* *}$ & 0.85 & 1.66 & 1.27 & 1.02 \\
\hline Moisture content (\%) & 52.50 & $116.05^{* *}$ & 0.55 & 1.69 & 3.12 & 1.67 & 2.74 & 1.42 & 1.02 \\
\hline Degrees of freedom & 1 & 1 & 1 & 4 & 20 & 20 & 20 & 20 & 76 \\
\hline
\end{tabular}

${ }^{2} \mathrm{Y}=$ year, $\mathrm{L}=$ location, $\mathrm{R}=$ replication, $\mathrm{P}=$ population, $\mathrm{E}=$ error.

${ }^{*, * *}$ Significant at $P \leq 0.05$ or 0.01 , respectively.

The number of the node of first flower, flowering date, and pod moisture content differed significantly between locations (Table 2). No significant differences between years for any of the traits were found. Genotype and environment interacted only for number of the node of first flower, flowering date, and number of tendrils. Flowering date and number of nodes to first flower have practical importance because they are used to predict the harvest date (Gritton, 1986); genotype-environment interactions for both also were observed by Snoad and Arthur (1974). This information indicates the necessity and importance of testing these populations in diverse environments.

Genotype-environment interactions ( $\mathrm{Y} \times$ $\mathrm{P}, \mathrm{L} \times \mathrm{P}, \mathrm{Y} \times \mathrm{L} \times \mathrm{P}$ ) were not detected for any of the pod traits (Table 2). The ANOVA shows significant differences among populations for pod length, width, length/width index, and fresh weight, but there is not a significant difference among environments (years and locations) for these traits. Goodman and Paterniani (1969) found that reproductive characters are more stable than vegetative characters.

Standard errors (SE) for population means (Y) in general were lower than $10 \%$, except for fresh pod weight, where sEs were slightly $>10 \%$ (Table 3 ). The range of variation shows the wide diversity present in the sugar pea populations, particularly for the number of nodes to first flower, flowering date, and pod length and width. Generally, these results indicate that the sugar pea landraces from the northwestern Iberian Peninsula constitute a wide genetic base. The wide genetic base of this material may be the most important characteristic of these sugar pea landraces, considering the problem of genetic vulnerability of many of the advanced cultivars. Additionally, these landraces may contain pure lines that could be useful as parental material.

The partial correlation coefficients (Table 4) between plant and pod traits are essential information for designing an effective breeding program. The greatest degree of relationship was found between pod physical traits, such as pod length with pod width, pod length with fresh pod weight, and pod width with fresh pod weight. In relation to pod length, varieties may be classified mainly into four groups (Makasheva, 1983): small (3 to 4.5 $\mathrm{cm})$; medium $(4.5$ to $6 \mathrm{~cm})$; large $(6$ to $10 \mathrm{~cm})$; or very large (10 to $15 \mathrm{~cm})$. The 20 sugar pea landraces studied fall in only two of the groups: 1) cultivars with very large pods, which included 'Capuchino' and three landraces, PSM-0070, PSM-0116, and PSM-0118. These materials may be considered good parents for increasing pod size. 2) The remainder belong to the group with large pods.

The introduction of edible-pod pea cultivars with thick walls and large pods has aroused much interest among home gardeners and may offer some possibilities for expanded commercial production and use. For home consumption, varieties must have long, thick, wide pods with no parchment layer. Landraces PSM-0064, PSM-0066, PSM-0117, and PSM0118 had the longest pod lengths and no parchment layer.

Node count to first flower was positively associated with flowering date $(r=0.39)$, but the relationship is weak. Similar results, but with higher values for this relationship, were found by Amurrio et al. (1993), which would indicate that, for earliness, small internodes and dwarf plants are desirable. Likewise, Gritton (1986) and Makasheva (1983) concluded that the number of nonfruiting nodes on the main stem was a relatively constant cultivar character that could be used to characterize duration of the vegetative period. The early maturing varieties flower first between nodes 8 to 12 above the cotyledonary node, while the medium-maturing varieties begin at nodes 13 to 16 , and the late varieties may not flower until about nodes 17 to 22 . Thus, the 20 landraces and the control variety are classifiable into only two groups. PSM-0070 and PSM-0116 are included in the early maturing varieties, and the remainder are mediummaturing varieties.

The landrace means for some traits compare favorably with the commercial control (Table 5). For example, PSM-0070 was the earliest to flower and possessed desirable pod length and width. PSM-0113 and PSM-0116 also were desirable for earliness and pod traits. Earliness is an important trait in this part of the Iberian Peninsula, where two crops of peas are produced each year.

Most of the sugar pea landraces segregated for two qualitative traits: flower color and presence or absence of the parchment layer in the ripe pod.

In conclusion, most of the 20 landraces probably were a mixture of pure lines. Sixteen were segregating for pod parchment. Pods of PSM-0064, PSM-0066, PSM-0117, and PSM0118 had no parchment, a condition that is found only in plants with the genetic constitution ppvv (Makasheva, 1983). This finding suggests that these four lines are pure sugar landraces. On the whole, they are neither particularly early nor desirable for pod physical quality; therefore, they could be included in a sugar pea breeding program as parents. How-

Table 3. Mean $(\overline{\mathrm{Y}})$, standard error $[\mathrm{se}(\overline{\mathrm{Y}})]$, coefficient of variation $(\mathrm{Cv})$, and range $(\mathrm{R})$ of plant and pod traits in sugar pea landraces from the northwestern Iberian Peninsula.

\begin{tabular}{lcccc}
\hline \hline Character & $\overline{\mathrm{Y}}$ & $\mathrm{SE}(\overline{\mathrm{Y}})$ & $\mathrm{CV}$ & $\mathrm{R}$ \\
\hline Plant traits & & & & \\
$\quad$ Node of first flower & 14.4 & 0.45 & 8.73 & $12.7-17.0$ \\
Flowering date (days) & 150.1 & 2.54 & 4.79 & $133.0-168.0$ \\
Number of leaflets & 4.5 & 0.20 & 12.36 & $4.0-5.2$ \\
$\quad$ Number of tendrils & 5.41 & 0.27 & 13.90 & $4.7-6.0$ \\
Pod traits & & & & \\
Length (mm) & 90.0 & 3.42 & 10.74 & $71.0-114.4$ \\
Width (mm) & 18.4 & 0.68 & 10.59 & $14.8-22.3$ \\
Length/width index & 4.9 & 0.12 & 6.44 & $4.4-5.5$ \\
Number of ovules & 7.7 & 0.15 & 5.56 & $7.0-8.2$ \\
Fresh pod weight $(\mathrm{g})$ & 3.07 & 0.36 & 32.89 & $1.8-5.5$ \\
Moisture content $(\%)$ & 87.4 & 0.36 & 1.15 & $85.9-88.5$ \\
\hline
\end{tabular}


Table 4. Partial correlation coefficients among plant and pod traits in sugar pea landraces from the northwestern Iberian Peninsula.

\begin{tabular}{|c|c|c|c|c|c|c|c|c|c|c|}
\hline Variable & $\mathrm{NF}$ & FD & NL & NT & PL & PW & PL/PW & OP & FPW & $\mathrm{MCP}$ \\
\hline Node first flower (NF) & 1.00 & & & & & & & & & \\
\hline Flowering date (FD) & $0.392^{* *}$ & 1.00 & & & & & & & & \\
\hline Number of leaflets (NL) & -0.165 & -0.179 & 1.00 & & & & & & & \\
\hline Number of tendrils (NT) & 0.077 & -0.016 & $0.317^{*}$ & 1.00 & & & & & & \\
\hline Pod length (PL) & 0.003 & -0.058 & -0.067 & -0.155 & 1.00 & & & & & \\
\hline Pod width (PW) & -0.050 & -0.114 & -0.043 & -0.117 & $0.831^{* *}$ & 1.00 & & & & \\
\hline Pod length/width (PL/PW) & 0.093 & 0.111 & -0.048 & -0.069 & $0.345^{* *}$ & $-0.224^{*}$ & 1.00 & & & \\
\hline Number of ovules per pod (OP) & -0.033 & 0.176 & -0.074 & -0.024 & 0.002 & -0.098 & 0.169 & 1.00 & & \\
\hline Fresh pod weight (FPW) & -0.048 & -0.044 & -0.148 & -0.108 & $0.870^{* *}$ & $0.876^{* *}$ & 0.041 & -0.100 & 1.00 & \\
\hline Moisture in pod (MCP) & 0.102 & -0.153 & 0.013 & -0.016 & 0.179 & $-0.283^{* *}$ & -0.283 & -0.166 & $0.266^{* *}$ & 1.00 \\
\hline
\end{tabular}

${ }^{*},{ }^{* *}$ Significant at $P \leq 0.05$ or 0.01 , respectively.

Table 5. Means of plant and pod traits for 20 sugar pea landraces from the northwestern Iberian Peninsula.

\begin{tabular}{|c|c|c|c|c|c|c|c|c|c|c|}
\hline \multirow[b]{2}{*}{ Germplasm } & \multicolumn{10}{|c|}{ Mean of plant and pod traits ${ }^{z, y}$} \\
\hline & $\mathrm{NF}$ & FD & NL & NT & PL & PW & PL/PW & OP & FPW & MCP \\
\hline Capuchino & $13.4 \mathrm{~g}-\mathrm{j}$ & $139 \mathrm{fg}$ & $4.2 \mathrm{~d}-\mathrm{g}$ & $5.8 \mathrm{ab}$ & $114 \mathrm{a}$ & $22.3 \mathrm{a}$ & $5.1 \mathrm{~b}-\mathrm{d}$ & $7.7 \mathrm{~b}-\mathrm{f}$ & $5.52 \mathrm{a}$ & $88.5 \mathrm{a}$ \\
\hline PSM-0022 & $14.4 \mathrm{~d}-\mathrm{h}$ & $145 \mathrm{c}-\mathrm{f}$ & $4.8 \mathrm{ab}$ & $5.4 \mathrm{a}-\mathrm{d}$ & $87 \mathrm{e}-\mathrm{i}$ & $19.0 \mathrm{ef}$ & $4.6 \mathrm{f}-\mathrm{h}$ & $8.0 \mathrm{a}-\mathrm{c}$ & $2.80 \mathrm{e}-\mathrm{h}$ & $87.6 \mathrm{a}-\mathrm{e}$ \\
\hline PSM-0040 & $15.2 \mathrm{~b}-\mathrm{e}$ & $153 \mathrm{~b}$ & $5.2 \mathrm{a}$ & $5.8 \mathrm{ab}$ & 711 & $14.9 \mathrm{i}$ & $4.8 \mathrm{e}-\mathrm{g}$ & $8.1 \mathrm{ab}$ & $1.81 \mathrm{~h}$ & $87.1 \mathrm{~d}-\mathrm{f}$ \\
\hline PSM-0064 & $16.3 \mathrm{ab}$ & $168 \mathrm{a}$ & $4.5 \mathrm{~b}-\mathrm{f}$ & $5.3 \mathrm{a}-\mathrm{d}$ & $95 c-e$ & $17.2 \mathrm{f}-\mathrm{h}$ & $5.5 \mathrm{a}$ & $7.0 \mathrm{~h}$ & $3.10 \mathrm{~d}-\mathrm{g}$ & $87.7 \mathrm{a}-\mathrm{e}$ \\
\hline PSM-0066 & $17.0 \mathrm{a}$ & $161 \mathrm{a}$ & $4.9 \mathrm{ab}$ & $5.3 \mathrm{a}-\mathrm{d}$ & $92 \mathrm{c}-\mathrm{g}$ & $17.5 \mathrm{fg}$ & $5.3 \mathrm{a}-\mathrm{c}$ & $7.3 \mathrm{f}-\mathrm{h}$ & $2.76 \mathrm{e}-\mathrm{h}$ & $87.3 \mathrm{~b}-\mathrm{f}$ \\
\hline PSM-0070 & $13.0 \mathrm{ij}$ & $133 \mathrm{~g}$ & $4.2 \mathrm{e}-\mathrm{g}$ & $5.2 \mathrm{c}-\mathrm{d}$ & $105 \mathrm{ab}$ & $21.4 \mathrm{a}-\mathrm{d}$ & $4.9 \mathrm{~d}-\mathrm{f}$ & $7.9 \mathrm{a}-\mathrm{e}$ & $4.88 \mathrm{ab}$ & $88.2 \mathrm{ab}$ \\
\hline PSM-0102 & $14.6 \mathrm{~d}-\mathrm{h}$ & $152 \mathrm{bc}$ & $4.6 \mathrm{~b}-\mathrm{f}$ & $5.7 \mathrm{a}-\mathrm{c}$ & $77 \mathrm{j}-1$ & $16.0 \mathrm{~g}-\mathrm{i}$ & $4.8 \mathrm{e}-\mathrm{g}$ & $7.5 \mathrm{~d}-\mathrm{g}$ & $2.14 \mathrm{gh}$ & $86.0 \mathrm{~g}$ \\
\hline PSM-0110 & $14.9 \mathrm{c}-\mathrm{f}$ & $152 \mathrm{bc}$ & $4.5 \mathrm{~b}-\mathrm{g}$ & $5.5 \mathrm{a}-\mathrm{d}$ & $80 \mathrm{i}-1$ & $17.4 \mathrm{fg}$ & $4.6 \mathrm{gh}$ & $7.7 \mathrm{~b}-\mathrm{f}$ & $2.28 \mathrm{gh}$ & $87.2 \mathrm{c}-\mathrm{f}$ \\
\hline PSM-0111 & $14.7 \mathrm{~d}-\mathrm{g}$ & $154 \mathrm{~b}$ & $4.7 \mathrm{a}-\mathrm{d}$ & $5.8 \mathrm{ab}$ & $86 \mathrm{e}-\mathrm{j}$ & $17.4 \mathrm{fg}$ & $5.0 \mathrm{c}-\mathrm{e}$ & $7.3 \mathrm{f}-\mathrm{h}$ & $2.38 \mathrm{f}-\mathrm{h}$ & $87.8 \mathrm{a}-\mathrm{e}$ \\
\hline PSM-0112 & $13.8 \mathrm{f}-\mathrm{j}$ & $143 \mathrm{~d}-\mathrm{f}$ & $4.2 \mathrm{c}-\mathrm{g}$ & $4.7 \mathrm{~d}$ & $93 \mathrm{c}-\mathrm{f}$ & $19.7 \mathrm{c}-\mathrm{e}$ & $4.7 \mathrm{e}-\mathrm{h}$ & $7.7 \mathrm{~b}-\mathrm{f}$ & $3.43 \mathrm{c}-\mathrm{e}$ & $87.7 \mathrm{a}-\mathrm{e}$ \\
\hline PSM-0113 & $13.4 \mathrm{~h}-\mathrm{j}$ & $141 \mathrm{fg}$ & $4.7 \mathrm{~b}-\mathrm{e}$ & $5.6 \mathrm{a}-\mathrm{c}$ & $99 \mathrm{~b}-\mathrm{d}$ & $21.8 \mathrm{ab}$ & $4.5 \mathrm{gh}$ & $8.2 \mathrm{a}$ & $4.17 \mathrm{bc}$ & $87.4 b-f$ \\
\hline PSM-0114 & $16.0 \mathrm{a}-\mathrm{c}$ & $164 \mathrm{a}$ & $4.2 \mathrm{~d}-\mathrm{g}$ & $5.3 \mathrm{a}-\mathrm{d}$ & $87 \mathrm{e}-\mathrm{i}$ & $17.4 \mathrm{fg}$ & $5.0 \mathrm{c}-\mathrm{e}$ & $7.7 \mathrm{~b}-\mathrm{f}$ & $2.61 \mathrm{e}-\mathrm{h}$ & $87.9 \mathrm{a}-\mathrm{d}$ \\
\hline PSM-0115 & $14.0 \mathrm{e}-\mathrm{i}$ & 143 ef & $4.6 \mathrm{~b}-\mathrm{f}$ & $5.7 \mathrm{a}-\mathrm{c}$ & $81 \mathrm{~h}-\mathrm{k}$ & $18.4 \mathrm{ef}$ & $4.4 \mathrm{~h}$ & $7.5 \mathrm{e}-\mathrm{g}$ & $2.63 \mathrm{e}-\mathrm{h}$ & $86.5 \mathrm{fg}$ \\
\hline PSM-0116 & $12.7 \mathrm{j}$ & $150 \mathrm{~b}-\mathrm{e}$ & $4.8 \mathrm{ab}$ & $6.0 \mathrm{a}$ & $102 \mathrm{bc}$ & $21.7 \mathrm{a}-\mathrm{c}$ & $4.7 \mathrm{e}-\mathrm{h}$ & $8.2 \mathrm{a}^{\circ}$ & $4.20 \mathrm{bc}$ & $86.8 \mathrm{e}-\mathrm{g}$ \\
\hline PSM-0117 & $13.6 \mathrm{~g}-\mathrm{j}$ & $141 \mathrm{f}$ & $4.0 \mathrm{~g}$ & $5.3 \mathrm{a}-\mathrm{d}$ & $83 \mathrm{~g}-\mathrm{k}$ & $15.8 \mathrm{~g}-\mathrm{i}$ & $5.3 \mathrm{a}-\mathrm{c}$ & $7.9 \mathrm{a}-\mathrm{d}$ & $2.27 \mathrm{gh}$ & $87.0 \mathrm{~d}-\mathrm{f}$ \\
\hline PSM-0118 & $16.2 \mathrm{ab}$ & $166 \mathrm{a}$ & $4.7 \mathrm{a}-\mathrm{e}$ & $5.7 \mathrm{a}-\mathrm{c}$ & $102 \mathrm{bc}$ & $19.8 \mathrm{c}-\mathrm{e}$ & $5.1 \mathrm{~b}-\mathrm{d}$ & $8.0 \mathrm{a}-\mathrm{c}$ & $3.31 \mathrm{c}-\mathrm{f}$ & $88.1 \mathrm{a}-\mathrm{c}$ \\
\hline PSM-0122 & $15.3 \mathrm{~b}-\mathrm{d}$ & $165 \mathrm{a}$ & $4.4 \mathrm{~b}-\mathrm{g}$ & $5.4 \mathrm{a}-\mathrm{d}$ & $76 \mathrm{kl}$ & $14.8 \mathrm{i}$ & $5.1 \mathrm{~b}-\mathrm{d}$ & $7.6 \mathrm{c}-\mathrm{g}$ & $1.81 \mathrm{~h}$ & $87.0 \mathrm{~d}-\mathrm{f}$ \\
\hline PSM-0123 & $14.3 \mathrm{~d}-\mathrm{h}$ & $151 \mathrm{~b}-\mathrm{d}$ & $4.7 \mathrm{a}-\mathrm{d}$ & $5.0 \mathrm{~cd}$ & $83 \mathrm{f}-\mathrm{k}$ & $15.3 \mathrm{hi}$ & $5.4 \mathrm{ab}$ & $7.2 \mathrm{gh}$ & $2.14 \mathrm{gh}$ & $86.8 \mathrm{e}-\mathrm{g}$ \\
\hline PSM-0124 & $13.3 \mathrm{~h}-\mathrm{j}$ & $141 \mathrm{f}$ & $4.8 \mathrm{a}-\mathrm{c}$ & $5.4 \mathrm{a}-\mathrm{d}$ & $95 \mathrm{c}-\mathrm{e}$ & $20.1 \mathrm{~b}-\mathrm{e}$ & $4.7 \mathrm{e}-\mathrm{h}$ & $8.2 \mathrm{a}$ & $3.99 \mathrm{~b}-\mathrm{d}$ & $87.5 \mathrm{a}-\mathrm{e}$ \\
\hline PSM-0125 & $13.8 \mathrm{f}-\mathrm{j}$ & $150 \mathrm{~b}-\mathrm{e}$ & $4.1 \mathrm{e}-\mathrm{g}$ & $5.1 \mathrm{~b}-\mathrm{d}$ & $91 \mathrm{~d}-\mathrm{h}$ & $17.7 \mathrm{fg}$ & $5.2 \mathrm{~b}-\mathrm{d}$ & $7.3 \mathrm{f}-\mathrm{h}$ & $3.15 \mathrm{~d}-\mathrm{g}$ & $87.0 \mathrm{~d}-\mathrm{f}$ \\
\hline PSM-0191 & $13.5 \mathrm{~g}-\mathrm{i}$ & $143 \mathrm{ef}$ & $4.1 \mathrm{fg}^{\circ}$ & $5.0 \mathrm{~cd}$ & $92 \mathrm{c}-\mathrm{g}$ & $19.7 \mathrm{de}$ & $4.7 \mathrm{e}-\mathrm{h}$ & $7.6 \mathrm{c}-\mathrm{g}$ & $3.02 \mathrm{~d}-\mathrm{g}$ & $87.4 \mathrm{~b}-\mathrm{f}$ \\
\hline Mean & $14.4^{\circ}$ & 150.1 & $4.5^{\circ}$ & 5.4 & $90.0^{\circ}$ & 18.4 & 4.9 & 7.7 & 3.07 & 87.4 \\
\hline LSD & 1.3 & 7.3 & 0.56 & 0.76 & 9.8 & 2.0 & 0.3 & 0.43 & 1.02 & 1.02 \\
\hline
\end{tabular}

${ }^{2} \mathrm{NF}=$ node of the first flower, $\mathrm{FD}=$ flowering date (days from sowing to flowering), $\mathrm{NL}=$ number of leaflets, $\mathrm{NT}=$ number of tendrils, $\mathrm{PL}=$ pod length $(\mathrm{mm})$, $\mathrm{PW}=$ pod width $(\mathrm{mm}), \mathrm{PL} / \mathrm{PW}=$ pod length/width, $\mathrm{OP}=$ number of ovules per pod, $\mathrm{FPW}=$ fresh pod weight $(\mathrm{g}), \mathrm{MCP}=\operatorname{moisture}$ content in pod $(\%)$.

${ }^{\mathrm{y}}$ Means separation within columns by LSD at $P \leq 0.05$.

ever, the heterogeneity present in the remaining 16 landraces also is of interest, because they could be subjected to selection.

This study has provided important information on the variability present in the sugar pea landraces from the northwestern Iberian Peninsula, which could be useful in a breeding program. We now have documentation that the 20 sugar pea landraces exhibit interpopulation and intrapopulation diversity for qualitative and quantitative characters that can be exploited in a breeding program to incorporate characteristics from some of these landraces into improved sugar pea varieties, or to establish pure line varieties by selection alone.

\section{Literature Cited}

Amurrio, J.M., A.M. de Ron, and M.R. Escribano. 1993. Evaluation of Pisum sativum landraces from the northwest of the Iberian Peninsula and their breeding value. Euphytica 66:1-10.

Goodman, M.M. and E. Paterniani. 1969. The races of maize III: Choice of appropriate characters for racial classification. Econ. Bot. 23:265-273.

Gritton, E.T. 1986. Pea breeding, p. 283-319. In: M.J. Basset (ed.). Breeding vegetable crops, AVI Publishing, Westport, Conn.

Makasheva, R.K. 1983. The pea. Oxonian Press, New Delhi, India.

Mateo Box, J.M. 1961. Leguminosas de grano, p.
200-217. SalvatEditores, Barcelona and Madrid, Spain.

Ron, A.M. de, R. Lindner, R.A. Malvar, A. Ordás, J.J. Baladrón, and J. Gil. 1991. Germplasm collecting and characterization in the north of the Iberian Peninsula. Plant Genet. Resources Nwsltr. 87:17-19.

Sneddon, J.L. 1970. Identification of garden pea varieties. (I) Grouping, arrangement, and use of continuous characters. J. Natl. Inst. Agr. Bot. 12:1-16.

Snoad, B. and A.E. Arthur. 1974. Genotype-environment interactions in peas. Theor. Appl. Genet. 44:222-231.

Steel, R.G.D. and J.H. Torrie. 1981. Principles and procedures of statistics: A biometrical approach. 2nd ed. McGraw Hill, New York. 